\title{
Educational Innovation through ICT-Mediated Learning Strategies in the Initial Teacher Education of English Language Teachers ${ }^{1}$
}

Innovación Educativa a través de Estrategias de Enseñanza Mediadas por las TIC en la Formación Inicial de Profesores de Inglés

Luis Jesús Rincón-Ussa, Yamith José Fandiño-Parra, and Andrea Margarita Cortés-Ibañez ${ }^{2 *}$

Universidad de La Salle, Colombia

1 Received: February 13th 2020/ Accepted: October 20th 2020

2 ljrincon@unisalle.edu.co; yfandino@unisalle.edu.co; ancortes@unisalle.edu.co 


\section{Abstract}

This paper describes the results of the first cycle of a co-joint action research study in methodological innovation in pre-service language teacher education at a private university in Bogotá, Colombia. The first part of the study consisted of implementing several ICT-mediated learning strategies that were designed considering the theoretical tenets of educational innovation, autonomy, and mediation. Strategies were implemented in three different academic spaces of a B.A. in Foreign Languages during the first semester of 2019. The purpose of this pedagogical implementation was to examine the value of ICT-mediated learning strategies for methodological innovation. The data analysis results, which were collected through a survey, indicate that ICT-mediated learning strategies play a fundamental role in methodological innovation because they promote collaborative and cooperative learning, foster autonomy, and self-directed learning. In addition, these strategies also seem to provide a range of possibilities for bolstering learning agency development on the part of the pre-service language teachers.

Key words: Teaching innovation; initial teacher education; English language teachers; ICT mediation; teaching strategies.

\section{Resumen}

Este articulo presenta los resultados del primer ciclo de una investigación acción. Este ciclo del estudio consitió en la implementación de varias estrategias de aprendizaje mediadas por diferentes herramientas techonoligcas. Estas estrategias fueron implementadas durante el primer semestre del 2019, por tres profesores, en tres espacios académicos diferentes en un programa de licenciatura en español y lenguas extranjeras, de una universidad privada, en la ciudad de Bogotá, Colombia. El propósito de estas implementaciónes fue comprender el valor de este tipo de estrategias para la innovación metodológica en la educación inicial de los docentes de lenguas extrajeras. Los datos se recopilaron a través de una encuesta y su análisis indica que el uso de estas estrategias puede promover el desarrollo del aprendizaje colaborativo y cooperativo, fomentar el desarrollo del aprendizaje autónomo, e igualmente ofrence multiples posibilidades para apalancar el desarrollo de la capacidad de agenciamiento del aprendizaje en la educación inicial de los profesores de lenguas extranjeras.

Palabras clave: Innovación docente; educación inicial docente; profesores de inglés;

mediación de las TIC; estrategias de enseñanza.

\section{Resumo}

Este artigo apresenta os resultados do primeiro ciclo de uma pesquisa ação. Este ciclo do estudo consistiu na implementação de várias estratégias de aprendizagem mediadas por diferentes ferramentas tecnológicas. Estas estratégias foram implementadas durante o primeiro semestre de 2019, por três professores, em três espaços acadêmicos diferentes em um programa de licenciatura em espanhol e línguas estrangeiras, de uma universidade particular, na cidade de Bogotá, Colômbia. O propósito destas implementações foi compreender o valor deste 
tipo de estratégias para a inovação metodológica na educação inicial dos docentes de línguas estrangeiras. Os dados se recopilaram através de uma pesquisa de opinião e a sua análise indica que o uso destas estratégias pode promover o desenvolvimento da aprendizagem colaborativa e cooperativa, fomentar o desenvolvimento da aprendizagem autónoma, e igualmente oferece múltiplas possibilidades para apalancar o desenvolvimento da capacidade de agenciamento da aprendizagem na educação inicial dos professores de línguas estrangeiras.

Palavras chave: Inovação docente; educação inicial docente; professores de inglês; mediação das TIC; estratégias de ensino. 


\section{Introduction}

r

eacher education should be an innovating endeavor in which future teachers learn the craft of teaching and, more importantly, where they learn to become innovators and agents of change. In this regard, UNESCO (1990) argues that innovation in teacher education refers to the design, implementation, and assessment of new ideas or practices in specific educational contexts created to meet unsatisfied needs. More concretely, it states that education innovation is "the introduction or promotion of new ideas and methods that are devised in education and school practices which have a substantial effect on changing the existing patterns of behavior of the group or groups involved" (p. 2). Consequently, methodological and pedagogical innovation constitute a dynamic field of study and a critical factor in ensuring the relevance and quality of future language teachers' education.

In this regard, Serdyukov (2017) maintains that teacher education can help society survive and thrive if it can serve its needs and interests. This capacity demands both a consistent and systematic curricular project and a revolutionary and disruptive formative experience. As a result, he claims:

Schoolteachers, college professors, administrators, researchers, and policymakers are expected to innovate the theory and practice of teaching and learning, as well as all other aspects of this complex organization to ensure quality preparation of all students to life and work (p. 4).

One way to ensure innovation in teacher education is through the use of ICT. This is so because as Ala-Mutka, Punie and Redecke (2008) explain, "New technologies, and especially social computing, provide new opportunities for education and training, as they enhance learning and teaching, and facilitate collaboration, innovation and creativity for individuals and organizations" (p. 6). To boost their effectiveness, they recommend encouraging experimentation with ICT so that teachers and students create new teaching and learning practices that benefit their local contexts. They also suggest improving ICT training of both pre-service and in-service teachers to ensure they learn and disseminate better practices thanks to media and digital technologies. Finally, they advise faculties of education to study ICT's impacts on teacher education, as empirical evidence is needed to describe how technology facilitates or enhances pedagogic innovation.

This action research study intended to shed some light on the value of ICTmediated learning and teaching strategies methodological innovation in the initial education of foreign language teachers. It is worth noting that this co-joint research project was part of an ongoing macro-research study in Didactic and Pedagogical Innovation in Higher Education. The first cycle of this research consisted of designing and implementing new learning strategies in different programs and disciplines. The 
second cycle consisted of consolidating pedagogical and methodological innovative strategies that could be replicable. Consequently, various research groups from other disciplines participated in the study whose primary purpose was to gain insights into pedagogical and educational innovation in higher education.

\section{Theoretical Framework}

Educational innovation and the use of ICT-mediated teaching and learning strategies are two concepts that have been discussed by different scholars. The literature review provides an interesting but complex view of epistemological perspectives and theoretical and methodological frameworks. What follows is a concise but complete account of the main definitions and positions found in academic sources.

\section{Educational Innovation}

Innovation comes from the Latin word innovare, which means into new. Then, it follows that the simplest definition of innovation is doing things in new ways or differently. To Sterberg (2017), innovation can be associated with a new idea, product, device, or novelty. It can also refer to a way of thinking beyond the present and into the future. As a process, it has to do with "generating and combining ideas to make a relationship between present accomplishments and past experiences to solve a future problem" (p. 2). For their part, Baregheh, Rowley, and Sambrook (2009) define innovation as "the multi-stage process whereby organizations transform ideas into new/improved products, service or processes, to advance, compete and differentiate themselves successfully" (p. 1334). Similarly, O’Sullivan and Dooley (2009) understand innovation as

the process of making changes, large and small, radical and incremental, to products, processes, and services that result in the introduction of something new for the organization that adds value to customers and contributes to the knowledge store of the organization (p. 5).

In education, innovation is understood as

the inducing of functional changes in new ways. It is the reworking of familiar fields of action to new circumstances, and the creation of new ways of perceiving and approaching problems (...) Innovation relies on an orientation toward flexible adaptation, experimentation, and guided change (UNESCO, 1996, p. 23).

Likewise, the OEDC/CERI (2010) understands innovation in education as 
"any dynamic change intended to add value to the educational process and resulting in measurable outcomes, be that in terms of stakeholders' satisfaction or educational performance... [it] focuses on how educational systems monitor and assess innovation and use the results to cumulate knowledge for action in this domain" (p. 12).

Redding, Twyman, and Murphy (2013) maintain that innovation consists of implementing an idea or invention, adapted or refined for specific contexts and needs. Such implementation continues over time, often with adjustments to fit the changes in the context. Over time, an innovation replaces the standard product, program, practice, or process with something better, and as the majority adopts it, the innovation then becomes the new standard (p. 6). In the same line of thought, Mykhailyshyn, Kondur, and Serman (2018) affirm that educational innovation is any new purposeoriented activity, organizational solutions, system, process, or method to ensure the development of educational organizations and their pertinence (p. 12).

These innovations include curricular innovation, pedagogical innovation, methodological innovation, technological innovation, and administrative innovation. They are defined as follows:

Table 1. Types of educational innovation.

\begin{tabular}{l|l} 
Type of innovation & Definition \\
\hline Curricular innovation & $\begin{array}{l}\text { Any change in aspects of a curriculum such as } \\
\text { philosophy, values, objectives, syllabi, materials, assessment, and learning outcomes, } \\
\text { among others. }\end{array}$ \\
\hline Pedagogical innovation & $\begin{array}{l}\text { A change of style in teaching and the organization of the educational process to introduce } \\
\text { new models of education that turn the education character in its essence and modify the } \\
\text { nature of the interaction of the teacher with the students. }\end{array}$ \\
\hline Methodological innovation & $\begin{array}{l}\text { An update of the content of educational programs in accordance with the best domestic } \\
\text { and foreign counterparts in order to introduce innovative courses creating modern content } \\
\text { and teaching practices. }\end{array}$ \\
\hline Technological innovation & $\begin{array}{l}\text { A use of new or improved learning technologies (such as distance education or online } \\
\text { learning, Internet technology, project organized technology, etc.) in order to provide } \\
\text { students and teachers with access to new resources, media, systems, etc. }\end{array}$ \\
\hline Administrative innovation & $\begin{array}{l}\text { An innovative structure or functioning that provides new educational services, } \\
\text { subdivisions, procedures, and processes. }\end{array}$
\end{tabular}

Source: Adapted from Mâță (2012) and Mykhailyshyn, Kondur, and Serman (2018).

In sum, educational innovation entails implementing new ideas, new practices, and new organizational and administrative mechanisms to directly or indirectly improve learning processes. It is also evident that educational innovation is a continuous endeavor that transforms educational institutions' culture, empowering all educational community members to be social transformation agents. 


\section{ICT-Mediated Teaching Strategies}

The classroom is the scenario in which educational innovation comes to life; amid the complex relations and interactions among the participants of learning processes, new strategies and ideas bear fruit if they are successful and validated by the immediate actors of educational processes. Over the last two decades or so, educational agents, institutions, and actors at all levels have deemed that the use of ICT is of paramount importance for the quality and improvement of educational systems, programs, and teaching practices. This need has given way to new notions, concepts, and theoretical frameworks that tackle the interplay of educational innovation, quality of education, and integration of ICT. Three of them are SAMR (Substitution, Augmentation, Modification, and Redefinition), TPACK (Technological Pedagogical Content Knowledge), and B-learning (blended learning).

On the one hand, SAMR describes three different levels of integration of ICT. The first one, substitution, is the level in which a technological tool is used to perform a learning activity without modifying the task, e.g., reading a book in a pdf file instead of reading it on paper. The second level, augmentation, consists of using a technological tool to enrich the learning activity somehow. The third level, modification, implies the use of technological tools to transform, in significant ways, the learning and teaching practices. The last level, redefinition, entails using technological tools to design learning experiences and scenarios that would not be possible without the mediation of those tools (Puentedura, 2012).

On the other hand, TPACK addresses the interplay of content, pedagogy, and technology. Understanding the intersection of these three domains produces knowledge that empowers teachers and learners to design and manage learning processes in which the balance of the three elements ensure the quality of learning experiences (Koehler, Mishra \& Cain, 2013). Finally, B-learning is an umbrella term that encompasses different methods and strategies that combine face-to-face instruction with ICT-mediated learning strategies. (Sharma \& Berrett, 2008). The overall purpose of b-learning is to "...optimizing achievement of learning objectives by applying the 'right' learning technologies to match the 'right' personal learning style to transfer the 'right' skills to the 'right' person at the 'right' time' (Singh \& Reed, 2001).

These theoretical constructs provide useful orientations and insights to understand, design, and implement methodological innovations at different educational levels. They also unveil questions about teacher education and training, such as integrating ICT with teachers' initial education to develop the knowledge and skills in using technology in their future professional practice? How to ensure the quality of educational processes using ICT? What is the role of ICT in changing the educational culture of B.A. programs in foreign languages? These inquiries served a general frame and guide in the development of this study. 
To shed light on the previous inquiries, teacher educators have resorted to teaching strategies designed and implemented through ICT, or more specifically to what some authors defined as Technology Enhanced Language Learning (TELL). To Walker and White (2013), TELL regards technology not merely as a tool to assist language learning, but "as part of the environment in which language exists and is used" (p. 9). This means that technology provides learners with an enriched context where language, communication, interaction, and learning occur in an articulated and purposeful way. Because of its enriched nature and variety, TELL allows teachers and learners to use and assess a greater range of teaching-learning strategies, which open space and time for dimensions such as connectivism, constructivism, interactionism, digitalization, and virtual reality, etc. Some of these strategies deal with structuring information, collaboration strategies, inquiry projects, and metacognition (Hernádez, Quiróz \& Olarte, 2016).

\section{Autonomy, Mediation, and Emancipation in Educational Innovation}

Ultimately, educational innovation aims at promoting new and better practices, processes, and products. Most of them have to do with enhancing teachers' and students' understanding and implementing principles such as autonomy, mediation, and emancipation. The word autonomy's origin goes back to Greece where it meant self-ruling from autos (self) and nomos (rule). Nowadays, it is understood as "the condition when an agent may determine the conception, the articulation and the execution of concepts, ideas and actions for him or her -self" (Motloba, 2018, p. 418). However, a literature review about autonomy indicates the co-existence of different but complementary theoretical perspectives (Erdocia, 2014). For instance, the Kantian perspective claims that exercise autonomy emerges from individuals' critical consciousness and their use of reasoning, as opposed to heteronomy, which is based on the acceptance of external coercive regulations. In political theory, autonomy is found in the classical model of democracy, and the idea of freedom understood from a liberal perspective.

In ELT, autonomy is defined as "the ability to take charge of one's own learning (Holec 1981, p. 3). To him, autonomy is the capacity one develops to do a series of actions in favor of one's learning. Some of those actions determine one's objectives, select methods, and techniques to reach those objectives, and monitor their progress towards them. For his part, Dam (1995) defines autonomy as both "a capacity and a willingness to act independently and in cooperation with others, as a socially responsible person" (p. 102). This way, autonomy is not just a capacity one acquires and executes but also a predisposition and attitude one develops and fine-tunes. 
When discussing autonomy, Littlewood (1999) describes two types: proactive and reactive. The former resembles Holec's definition as it deals with a self-initiated assumption of one's learning. The latter has to do with one's response to an external stimulus to encourage one to organize resources to achieve an objective. In 2005, Benson described three versions of autonomy in ELT: the technical, the psychological, and the political. The technical version relates to the learning of a language outside educational institutions without the assistance of teachers. It focuses on the promotion of life-long learning. The psychological version deals with the attitudes and emotions learners should construct to learn languages responsibly. It emphasizes understanding the mental and affective characteristics students need to be autonomous. The political version has to do with the control learners need to have of the process and learning context. It revolves around the awareness students must develop about the purposes, the implications, and the potentials of learning for personal and social change.

This co-joint research project is also underpinned by Fox and Riconscente's (2008) discussion on self-regulation and metacognition to complement autonomy. These authors analyzed these two constructs by looking back at the roots in James, Piaget, and Vygotsky's theories. To James, self-regulation and metacognition are inwardly directed activities of the self, which are automated as habits and exercised through efforts in terms of a will. For his part, Piaget stated that metacognition and selfregulation are fundamental knowledge of and control of others and objects, a view of one's thoughts and actions as having the same position and following the same rules as relations with these external realities (Fox \& Riconscente, 2008). On the other hand, Vygotsky declared that metacognition is the mind's activity in which one is conscious of being conscious. Simultaneously, self-regulation is implied as one needs to be aware of being self-regulated in his learning process. Nevertheless, this process requires having passed the childhood stage and having social interactions with others so that such a process can become internalized.

Undoubtedly, various studies have used the terms of self-regulated learning and self-directed learning indistinctively. Nonetheless, Loyens, Magda, and Rikers (2008) clarify these terms' similarities and differences. To begin with, both include active engagement as well as a set of goals to achieve. They also develop metacognitive skills. However, self-directed learning is broader than self-regulated learning. The first one infuses the school environment with new practices and discourses, while the latter is a personal feature students need to acquire and develop to define what they want to learn.

It is important to point out that the underpinning principles of this notion derive from diverse disciplines and fields of knowledge regarding mediation. These tenets interweave, creating a theoretical framework that allows a dynamic dialogue among disciplines such as psychology, sociology, pedagogy, and anthropology, among others. In this respect, Tebar (2003) stated that pedagogical mediation's paradigm contributes 
to renovating schooling altogether based on fraternity and hope for everyone. Likewise, Manen (1998) affirmed that mediation occurs when the pedagogical and educational processes acknowledge human and social particularities.

The concept of mediation is an integral part of formal and informal adult learning, conceived not as an isolated act of cognition, but rather as interaction via mediation. In this process, learners become competent or proficient as other participants, such as teachers and peers, assist them in learning. As a result, teacher educators' role is to act as mediator figures who work as intermediaries between general programmed contents and specific situated practices. To Azadi, Biria, and Nasri (2018), teacher educators need to provide pre-service teachers with various kinds of mediations so that their academic, disciplinary, and personal development is facilitated and consolidated. This variety can be achieved if teacher educators act as "(i) facilitators of the learning of heuristics, (ii) mediators of knowledge sources, (iii) mediators of lifelong learning, and (iv) designers of the learning environment." (p. 136). Ultimately, teacher educators should act as mediators who help pre-service teachers conceptualize and utilize theory, skills, and attitudes for their classroom practices and formative experiences.

Concerning emancipation, Adorno (1998) defines it as a theory that reflects critically going beyond instrumental rationality that examines reality to control it. Instead, it proposes rationality that seeks to transform reality into a more just and egalitarian experience. To Berrío (2016), emancipation is a form of resistance to current society, its structures, history, and nature itself, but to transform the structures that have denied subjectivity and made it impossible to carry out a project genuinely liberating. In relation to ICT, emancipation implies reflecting on repressive socialization processes and the various social control mechanisms that thwart critical individuals from developing (Binimelis, 2010).

Undoubtedly, emancipation is associated with the work of Habermas (1971 as cited by Adorno, 1998) when he discusses the three interest of knowledge and human interest: technical (the empirical-analytic approach), practical (the hermeneutic approach) and emancipatory (the critical approach). To him, the discovery and construction of knowledge should include but do not limit to predicting/explaining the physical world or interpreting/understanding social realities. Instead, knowledge discovery and construction should lead to a transformed consciousness that allows one to make informed decisions and actions to improve one's sense of who one is and change one's expectations of what one can do.

Such transformed consciousness demands, among other things, reflection, agency, and empowerment. Besides facilitating a dialogue between theory and practice, reflection encourages teachers to move from empirical/practical doing to reflective/ critical practice. In other words, reflection takes teachers "from applying learned pedagogical discourse to creating pedagogical know-how, specifically know-how that enables them to criticize and transform their practice and reality" (Restrepo, 2004, as 
cited by Fandiño, 2010, p. 115). For its part, the agency has to do with "the creation of local plans and projects for the use and development of resources in response to one's interests and particular problems" (Baldauf, 2006, as cited by Fandiño \& Bermúdez, 2016 , p. 13). It is essential to point out that agency is not something that teachers can have - as a property, capacity, or competence - but is something that they do. In other words, agency denotes the quality of teachers' engagement with temporal-relational contexts-for-action, not a quality of the teachers themselves, which means that agency is understood as an emergent phenomenon of teacher-situation transaction (See Biestaab, Priestleyc \& Robinson, 2015). Finally, empowerment presupposes a process by which teachers develop, increase and validate their experience, decision-making, and authority to have an active voice in their educational practices and circumstances (Fandiño, Bermúdez \& Varela, 2016). Empowerment in education, then, consists of processes where institution participants acquire the competence to take charge of their development, and from it, they can address or resolve their problems by developing the mechanisms that are necessary to do so (Kimwarey, Chirure, and Omondi, 2014).

\section{Methodological Framework}

\section{Paradigm, Approach, and Type of Study}

This study embraces the socio-critical paradigm since self-critical reflection is the core of social practices that produce the knowledge that transforms culture. This means that "doing and thinking are complementary [since] doing extends thinking in the tests, moves, and probes of experimental action, and reflection feeds on doing and its results. Each feeds the other and each sets boundaries for the other" (Schön, 1983, p. 280).

The study's purpose and nature are also aligned with the tenets of qualitative research that views individuals as active agents in constructing and determining realities (Cook \& Reichardt, 2005). According to SeeVerd \& Lozares (2016), qualitative research has three distinctive features: (1) the language used to analyze data is based on the discourse, (2) the perspective of the subjects and the relation to the theoretical issues will be of great importance, and (3) the informative richness of data allows understanding the social phenomena that the subjects are experiencing. These characteristics also framed and oriented the development of the study.

This study followed the overarching principles and characteristics of action research in education as its guiding research method. In view of Carr and Kemmis (1988), action-oriented research has four distinctive tenets: (1) commitment to social practice, (2) intention to improve, (3) use of recursive cycles, and (4) adherence to reflection. Attention to these principles entailed ongoing reflection, collaboration, and solidarity to pursue collective understanding and meaning negation and construction. 


\section{Data Collection and Analysis}

In line with the previous general guiding principles, a combination of closed- and open-ended questions allowed collecting participants' voices and perceptions during the first cycle of the research. The emergent interpretations and insights helped the researchers to relate the studied phenomena with the theoretical framework.

The survey consisted of three parts: Part I: participants' perceptions about the relevance of the learning strategies and TIC, Part II: participants' beliefs about the effectiveness of the learning experience, and Part III: participants' attitudes towards the appropriateness of the learning process. This survey was designed in accordance with Gray's (2004) five-stage process: (a) survey design and preliminary planning, (b) piloting, (c) final survey design, (d) data collection, and (e) data analysis and reporting.

Researchers undertook the data analysis as "a set of manipulations, transformations, operations, reflections and verifications made from data to extract relevant meaning regarding a research problem" (Gil, 1994, as cited in Bisquera, 2004, p.153). Besides, this process of meaning-extraction and construction followed the steps of (1) data reduction, (2) data representation, and (3) data interpretation proposed by Rodríguez, Gil, and García (1999).

\section{Pedagogical Intervention}

In this co-joint research project, three teacher-educators from a B.A. program in Spanish and Foreign Languages worked together during the second semester of 2018. They designed and implemented innovative ICT-mediated learning activities and learner-centered strategies in three different academic spaces. Such activities and strategies were used to boost the learners' autonomy, self-directed learning, and agency. Researchers selected the technological tools and designed the learning strategies bearing in mind the purposes mentioned above and considering the underpinning theoretical principles of Autonomy, mediation, educational innovation, and ICTmediated learning strategies.

Table 2 below shows the academic spaces, the participants, the strategies, and the tools. 
Table 2. Spaces, participants, ICT tools and strategies used in this pedagogical intervention.

\begin{tabular}{l|c|l} 
Semester / subject matter & $\begin{array}{c}\text { Number of } \\
\text { participants }\end{array}$ & \multicolumn{1}{|c}{ ICT tools / strategies implemented } \\
\hline Third semester / English language & 19 & $\begin{array}{l}\text {-Virtual classroom / forums, workshops, co-evaluation tasks } \\
\text {-Blog / E-learning journal } \\
\text {-Website / elaboration of vocabulary study sets }\end{array}$ \\
\hline Sixth semester / English didactics & 12 & -Websites / elaboration of graphic organizers \\
\hline Fourth semester / English language & 12 & $\begin{array}{l}\text {-Language learning Platform / flipped classroom-liked activities } \\
\text {-Moodle Platform / entry and exit tests } \\
\text {-WhatsApp / Peer monitoring activities and communication channel }\end{array}$
\end{tabular}

Source: Own elaboration.

The first pedagogical implementation consisted of the use of a virtual classroom, a blog, and a website to develop several collaborative and cooperative ICT-mediated learning activities: An E-learning journal, forums, co-evaluation activities, and vocabulary development activities. The E-learning journal was a blog in which students compiled written products, written feedback, and a reading log. The forums were part of a virtual classroom where learners shared and assessed peers' written posts and videos. The third activity, co-evaluation, consisted of a workshop in a virtual classroom in which learners published, assessed, and commented on other groups' E-learning journal. The vocabulary development activities consisted of the collaborative construction of study sets on a web site. Thirty-five students of the third semester developed these strategies during one semester. 19 out of the 35 students answered the survey about the strategies at the end of the semester.

Twelve students from the sixth semester of an English didactics course participated in the second pedagogical implementation. It involved the explicit and systematic use of different online websites to design and elaborate graphic organizers. The graphic organizers used in a sequential order where synoptic charts (Summaries), comparative charts (comparisons), timelines (sequence of events), mind maps (part-and-whole relationships), concept maps (relations among concepts), and semantic maps (webs of words). The websites used were www.canva.com, www.infograph.com, www. mindmapfree.com, www.wisemapping.com, www.creately.com/lp/concept-mapmaker, www.smartdraw.com, and www.visualthesaurus.com. This number of websites offered students the possibility to know different online alternatives to choose the ones that best fit their interests and needs. This work sought to promote the construction of knowledge, the organization of information, problem-solving, and decision-making. Out of 12 students, 6 students answered the survey at the end of the academic term.

Eighteen students of an English language course participated in the third implementation. At the beginning of the course, an entry test was created in Moodle 
and applied to know students' previous knowledge; then, at the end of the course, an exit test, which was the same they presented at the beginning, was done. The objective of this was to know if students had had progress in their learning process. The other tool was an online platform in which students did different type of activities in preparation for the face to face class. In these sessions, students were expected to put into practice what they had prepared beforehand. During this process, a group in WhatsApp was created for peer monitoring, sharing materials, practicing speaking, and reading and listening. In total, twelve students answered the survey.

\section{Findings and Results}

The following figures present the six categories that emerged from the first cycle of this co-joint action research project: 1. Level of Satisfaction with the Learning Outcomes and The Strategies; 2. The value of the Technological Tools for the Learning Process; 3. Methodology and the Development of Autonomy, Self-directed Learning, and Agency; 4. The impact of ICT on the Learning Process of Pre-Service Teachers; 5. ICT and the Accomplishment of Learning Objectives in Initial Teacher Education; 6. The Value of ICTs for Methodological and Pedagogical Innovation in the Initial Education of Foreign Language Teachers.

\section{Level of Satisfaction with the Learning Outcomes and The Strategies Implemented}

Figure 1 shows the relationship between the overall level of satisfaction with the learning outcomes achieved and the ICTs-mediated learning strategies and activities. These strategies aimed to promote autonomous learning, the learner's participation, and the construction of knowledge and meanings. The respondents' answers indicate an adequate level of gratification with the ICTs-mediated in promoting the aspects mentioned before. The overall level of satisfaction of the learners with the learning outcomes showed the highest level. The line of tendency (totally agree and agree) shows a positive linear correlation between the ICTs-mediated learning strategies implemented and the overall satisfaction with the learning outcomes achieved. 
Las estrategias de aprendizaje promovieron el aprendizaje autónomo

Las estrategias y actividades de aprendizaje promovieron la participación activa

Las estrategias y actividades de aprendizaje promovieron la construcción de conocimiento y significados

Me siento satisfecho con los aprendizajes logrados gracias a las actividades realizadas en esta asignatura.
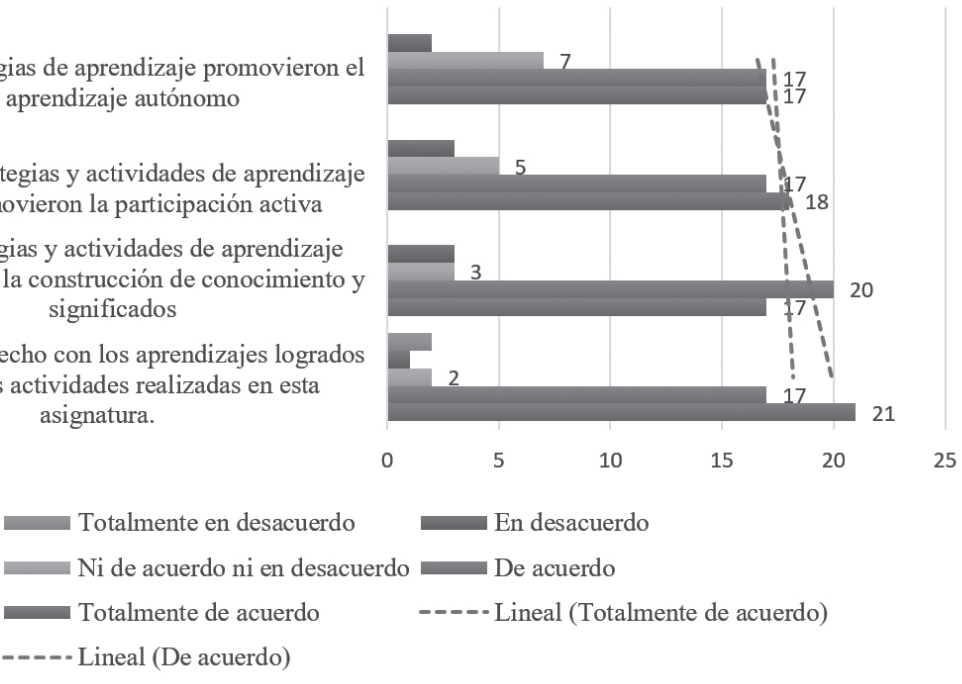

Figure 1. Level of satisfaction with the learning outcomes and the strategies implemented.

\section{The value of the Technological Tools for the Learning Process}

This category comprises the results of the value of the technological tools in leveraging the learning process. The use of the technological tools seems to foster collaborative learning, decision making that improves academic attainment, and allow the learner to do activities according to his learning pace and capacity. The results indicate that pre-service teachers value the role of technological tools in developing the aspects mentioned above. The lines of tendency (totally agree and agree) show a positive linear correlation between the use of the tools and their overall value in leveraging the learning process, which is the element with the highest score. Largely, it seems that technological tools might be directly correlated with the learning process's effectiveness and efficiency in developing learning skills and attitudes essential for the educational process. 
La herramientas y recursos tecnológicos facilitaron el trabajo y aprendizaje colaborativo

Las herramientas tecnológicas usadas me permitieron tomar decisiones para mejorar mi desempeño académico

Las herramientas tecnológicas usadas me permitieron desarrollar actividades según mi ritmo y capacidad de aprendizaje

Las herramientas tecnológicas usadas fortalecieron el proceso de aprendizaje
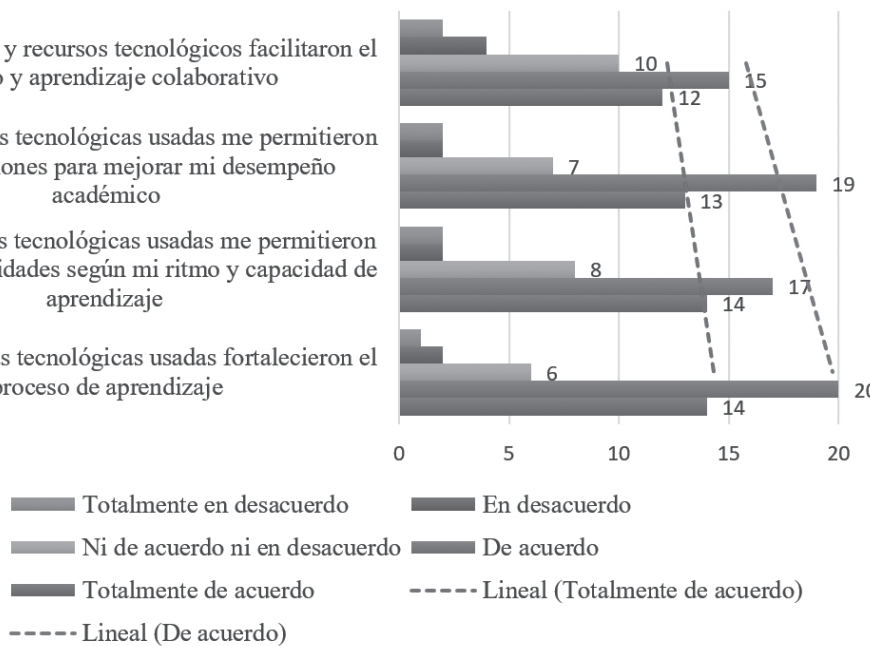

En desacuerdo

De acuerdo

- - - Lineal (Totalmente de acuerdo)

- - - Lineal (De acuerdo)

Figure 2. The value of the technological tools for the learning process.

\section{Methodology and the Development of Autonomy, Self- directed Learning, and Agency}

In this category, the figure portrays the relationship between the general methodology of the academic spaces and the development of skills and attitudes concerning autonomy, self-directed learning, and agency. In particular, the results suggest students valued making decisions about the learning process according to the learners needs and interests; doing self-evaluation of the learning process, identifying their strengths and weaknesses; and planning the learning process. Broadly, the voice of the pre-service foreign language teachers, represented in Figure 2, inform that the methodology and the strategies implemented had a moderate impact on developing skills and attitudes that allowed them to take control of the learning process and becoming independent learners in different ways. 


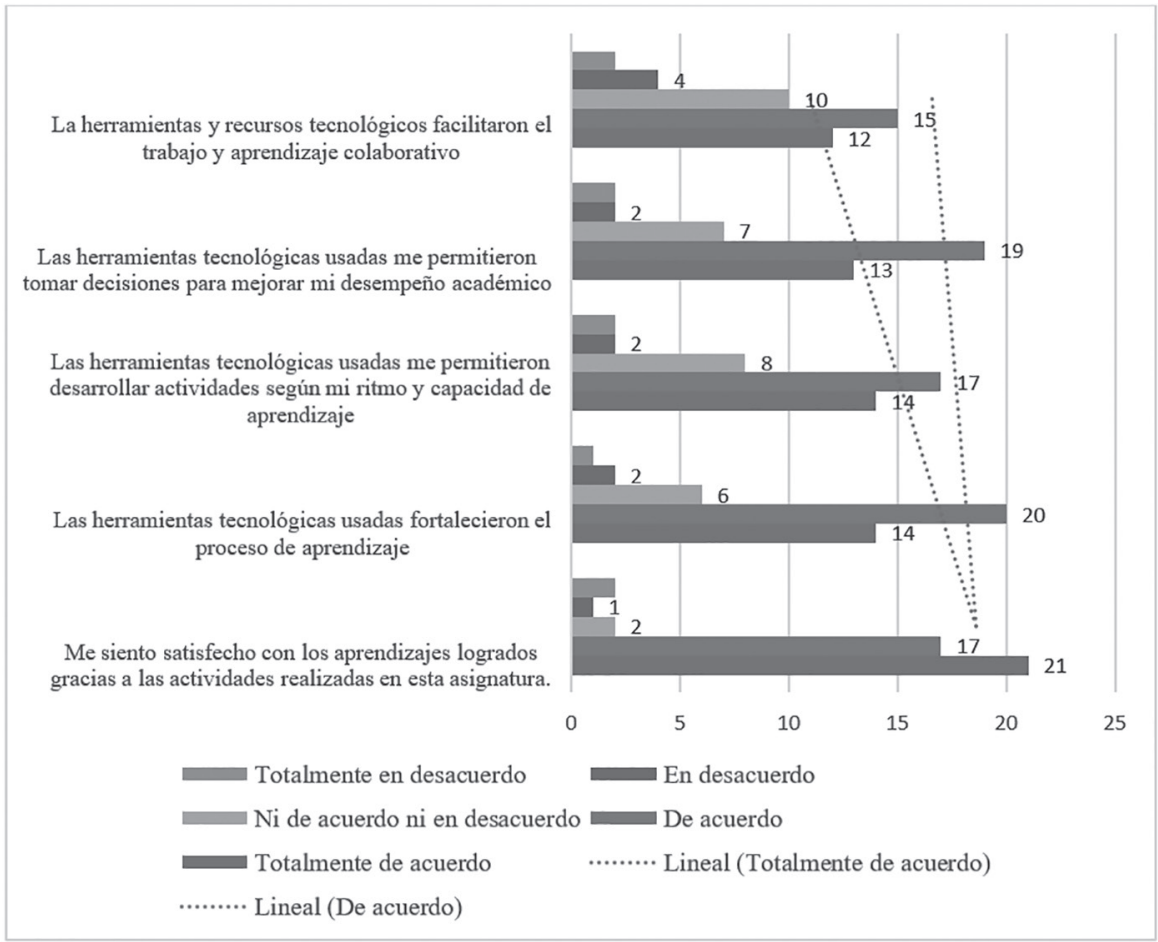

Figure 3. Methodology and the development of autonomy, self-directed learning, and agency.

\section{The impact of ICT on the Learning Process of Pre-Service Teachers}

Overall, data show ICTs help innovate methodology in initial teacher education. This is so as this innovation appears to provide future teachers with activities and resources that suit their needs and interests, boosting their metacognition and understanding of their learning. Concretely, the graph shows that the level of preservice teachers' satisfaction with the accomplishment of learning outcomes was high, as most of them seemed to believe that the activities carried out in their academic spaces helped them achieve their learning goals. The lines of tendency (strongly agree and agree) indicate a positive linear correlation between technological tools and the overall level of satisfaction with the level of the learning achievements. Also, they appear to regard as favorable the fact that the use of ICT allowed them to do 
activities according to their learning pace and capacity. This assessment seems to correlate positively with pre-service teachers' sense of strengthening their learning process thanks to ICT use. However, data suggest future teachers may need more or better opportunities to perceive ICTs as a facilitating or assisting resource in terms of decision-making and collaborative work. Overall, there is a strong underlying correlation between technological tools and the general level of satisfaction with the level of learning attainment.

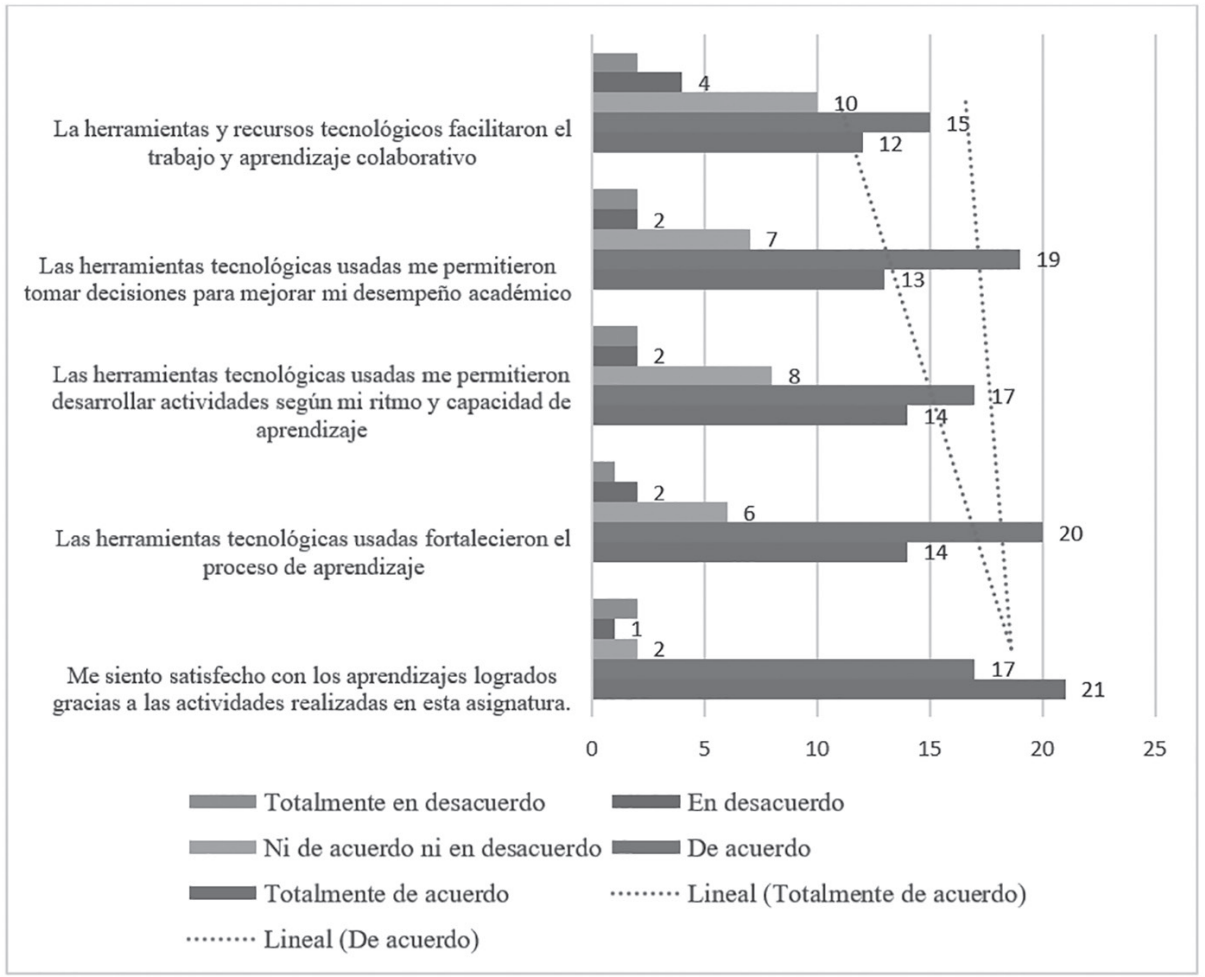

Figure 4. The role of ICT in the methodological innovation of pre-service teachers.

\section{ICT and the Accomplishment of Learning Objectives in Initial Teacher Education}

By and large, this category presents information that suggests that the use of ICTs does help future teachers accomplish the learning objectives. This appears to be so as the participants' responses indicate that ICT favor three specific aspects: level of transference, level of learning achievement, and level of learning strengthening. The 
first aspect reflects pre-service teachers' perceptions about their capacity to transfer what they learned in the academic spaces being intervened in other academic spaces. In other words, they could use or implement the ICT-mediated strategies in other classes. The second aspect shows pre-service teachers' satisfaction with the learning they achieved because of the activities done in classes based on the new teaching strategies. The third aspect supports the second one, as pre-service teachers appear to think the technologies used in the academic spaces help them strengthen their learning process; put differently, the learning process of future teachers optimizes thanks to ICT-mediated strategies. On the other hand, collaboration, learning pace, and academic performance can require some reinforcement as the participant preservice teachers' responses show an average overall rating.

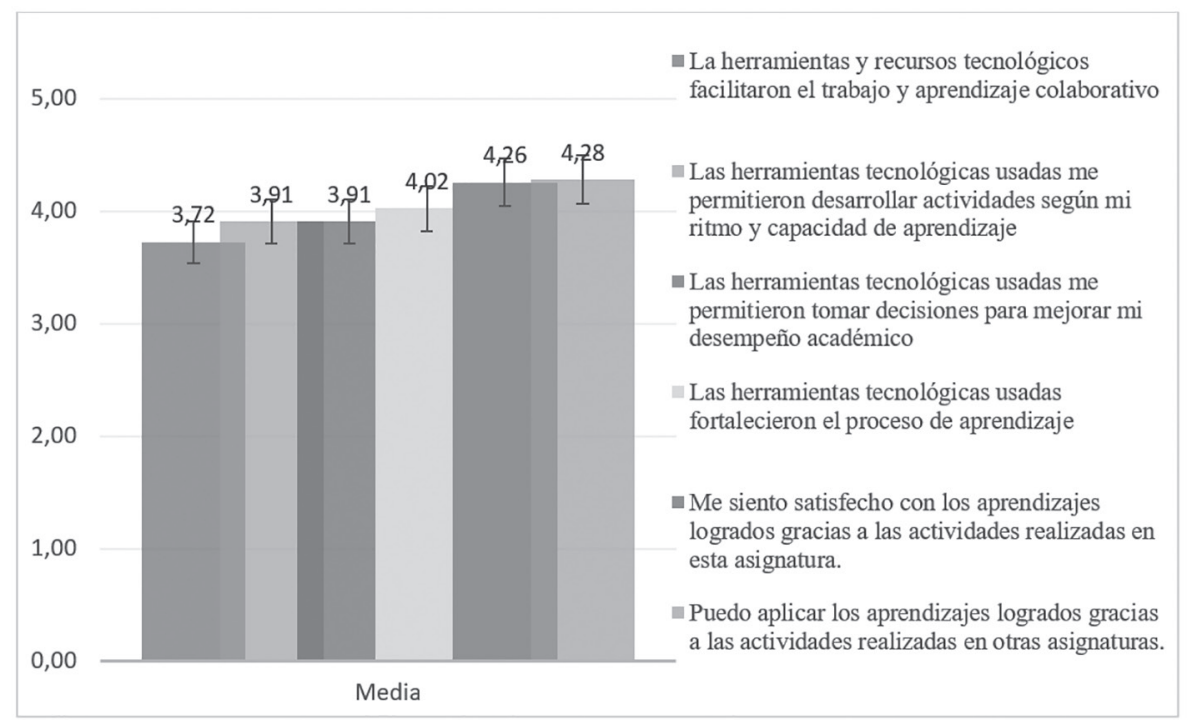

Figure 5. ICT and the level of accomplishment of the learning process.

\section{The Value of ICTs for Methodological and Pedagogical Innovation in the Initial Education of Foreign Language Teachers}

Data refers to the methodology and technological tools regarding the pre-service teachers' learning process in this category. It can be noticed that most respondents agreed that the methodology of the subject fostered the capacity to plan their academic process as well as it helped them make their own decisions and act, bearing in mind 
their needs and interests. Moreover, the methodology encouraged students to do a self-assessment on their process. On the other hand, a high percentage also shows that technological tools appear to boost their learning process. It is also noticeable that technological tools let students make decisions to improve their academic learning. Furthermore, they promote cooperative learning.

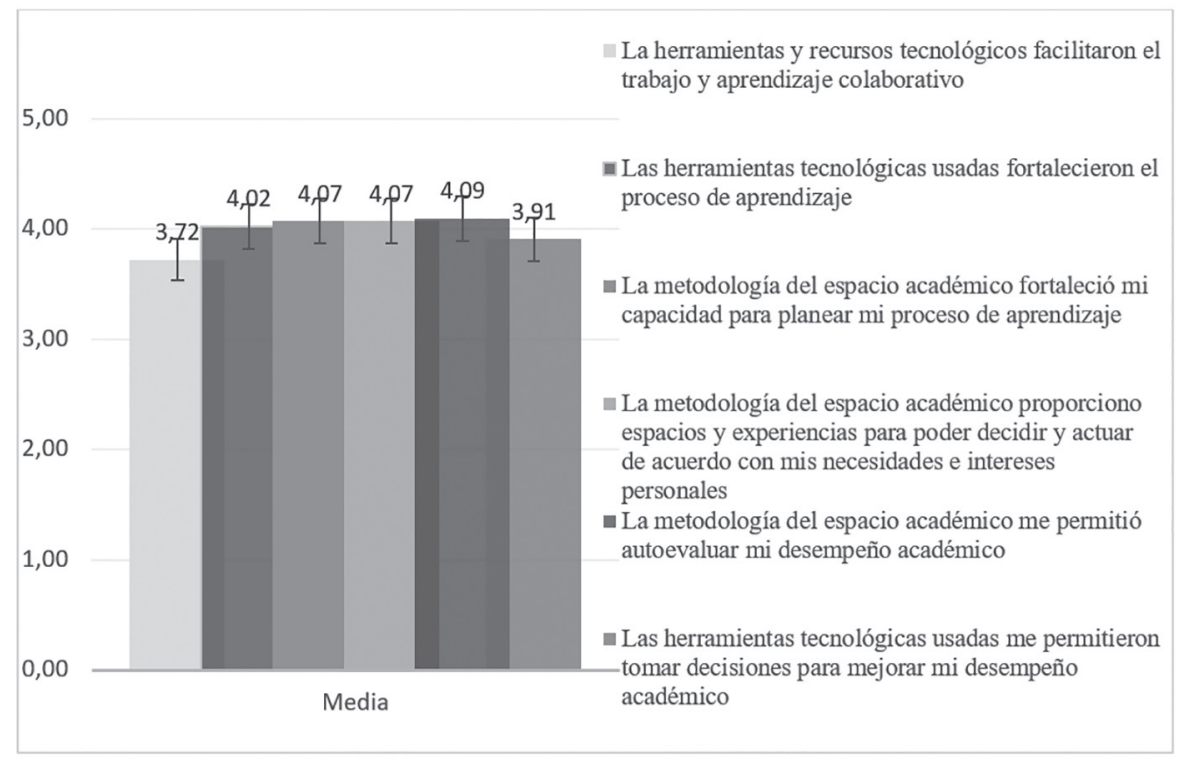

Figure 6. ICT and methodological innovation in the initial education of language teachers.

\section{Discussion}

The different technological tools and strategies implemented in the different academic spaces positively impacted several elements of the learning process. Firstly, it seems that there is a correlation between the ICT-mediated learning strategies and the level of attainment of the learning outcomes. Besides, it is relevant that the learners recognize the value of the ICT-mediated strategies to bolster the learning process, improve their academic performance, and plan the learning process. All these elements are essential in promoting the learner's autonomy, self-directed learning, and agency. In this regard, Mostafa, Ahmad, Sosahabi and Berahman (2017) state that "ICT plays an effective role via creating motives, deepening and expanding teaching and sustaining learning as well as removing pervasive boredom and creating subjective skills" (p. 697). 
Another aspect that the learners' value is the role of ICT in facilitating decisionmaking about the learning process and developing learning activities according to their capacity and learning pace. Consequently, it seems that the use of technological tools might promote students' empowerment and ownership of the learning process. This indicates that the ICTs-mediated learning strategies afford the teacher possibilities to develop differentiated and tailored strategies that acknowledge diverse learning styles, levels, and paces. Similarly, Kler (2014) states that "ICT fulfills the needs of the individual learner and also helps them in their learning by motivating them to learn and in this way the learners learn better and in a more effective manner" (p. 256).

A third relevant element is that integrating ICTs seems to be a fundamental factor in methodological innovation in the classroom. This process, however, brings up challenges. On the one hand, it entails the reformulation of the roles of the teacher and the learner. On the teacher's side, he positions as a strategic mediator of the learning process. Someone who designs learning environments in which the pre-service teacher finds diverse learning paths that facilitate the attainment of learning outcomes and agency development. This means the capacity of making decisions about his learning process; assessing his progress and growth; planning and implementing learning strategies; identifying and overcoming hindrances that thwart his steady progress and development. In sum, the comprehensive implementation of ICT-mediated learning strategies empowers the teacher-educator as a transformative agent, who purposefully fosters self-directed and regulated learning and develops a mindset of autonomy and continuous professional growth.

On the part of the learner, it implies that he takes responsibility for his learning process, which means that he can make informed decisions, evaluate and plan his learning process. The reformulation of the roles in the learning process implies the change of the relationships between the participants of the learning process and the dynamics of the learning environment; in other words, the continuous reformulation of the educational culture. When discussing the challenges of teaching and learning with ICT, Shan (2013) maintains that teachers and learners need autonomy, capability, and creativity to be able to develop qualitative teaching and learning with ICT. Among other things, this means they need to acquire and develop new roles and actions to take control of the teaching-learning experience; they can apply and transfer knowledge. They can use new multimedia tools and materials.

Largely, the concrete and situated methodological innovations that integrate ICT constitute opportunities for Classroom-based educational innovation. These small-scale innovations provide insights that promote the collective and collegiality academic discussion needed to drive curricular change, which might produce the adjustment of the organizational and administrative structures and the evolution of the educational community's educational culture. Even more, these situated processes shed light on larger-scale educational innovation endeavors and even might have a significant impact on regional educational policies. 


\section{Conclusions and Pedagogical Implications}

As a whole, the results indicate that pedagogical and methodological innovations that integrate ICTs in the initial education of pre-service foreign language educators might contribute to:

- fostering the development of skills and attitudes in collaborative and cooperative learning,

- $\quad$ promoting the development of autonomy and self- directed learning,

- $\quad$ enhancing awareness, on the part of the learners, about the learning process and developing skills and attitudes in taking control of it,

- providing a range of possibilities for bolstering emancipatory agency throughout the education process of pre-service foreign language teachers,

- $\quad$ engendering classroom-based educational and pedagogical innovation, and

- empowering future language teachers with experiential-based knowledge about the value of ICTs in language learning and teaching.

- $\quad$ On the other hand, pedagogical and methodological innovative practices that integrate ICTs bring up some challenges and implications. Such challenges and implications are as follows:

- $\quad$ Technology-enhanced teaching strategies need to provide pre-service teachers with interactive activities and reflective experiences that enable them to address their interests and needs from multiple perspectives and complexity levels. This entails competencies, skills, and attitudes in using ICTs on the teacher and the students.

- Methodological and pedagogical innovations that integrate ICTs need to be fully integrated with academic programs and instructional practices, which implies that they need to be selected strategically based on their features and their use to support concrete learning aims. This brings up the need for organizational conditions and dynamics that facilitate collective dialogue and collegially amongst all the educational process actors.

- Pedagogical and methodological innovations that integrate ICTs need to allow room for tools and environments that help learners control and mediate their learning through multiple inquiry and self-reflection pathways. This implies that the educator of pre-service foreign language teachers assumes the role of a skillful strategic mediator whose skills and attitudes empower him to design, implement and evaluate learning paths that are aligned with the nature of the language learning process and the particular socio-cultural context of the learner. 


\section{References}

Azadi, G., Biria, R., \& Nasri, M. (2018). Operationalizing the Concept of Mediation in L2 Teacher Education. Journal of Language Teaching and Research, 9(1), 132-140. DOI: http://dx.doi.org/10.17507/jltr.0901.17

Azevedo, R. (2005). Using hypermedia as a metacognitive tool for enhancing student learning. The role of self-regulated learning. Educational Psychologist, 40(4), 199209.

Adorno, Th. W. (1998 [1959-1969]). Educación para la emancipación: conferencias y conversaciones con Hellmut Becker (J. Muñoz, trad.). Madrid: Ediciones Morata.

Ala-Mutka, K., Punie, Y., \& Redecker, C. (2008). ICT for learning, innovation, and creativity (Policy brief). Luxembourg: Joint Research Centre of the European Community.

Baregheh, A., Rowley, J., \& Sambrook, S. (2009). Towards a multidisciplinary definition of innovation. Management decisions, 47(8), 1323-1339.

Benson, P. (2005). Teaching and researching autonomy in language learning. Beijing: Foreign language teaching and research press.

Berrío, A. (2016). La superación de la barbarie, la emancipación del sujeto y la autoreflexión crítica: Fines del proyecto educativo en Theodor Adorno (Tesis de maestría). Universidad del Norte, departamento de humanidades y filosofía, Barranquilla, Colombia.

Biestaab, G., Priestleyc, M., \& Robinson, S. (2015). The role of beliefs in teacher agency. Teachers and Teaching: Theory and practice, 21(6), 624-640. DOI: 10.1080/13540602.2015.1044325

Bisquera, R. (Coord.) (2004). Metodología de la investigación educativa. España: Editorial La Muralla.

Binimelis, H. (2010). Hacia una sociedad del conocimiento como emancipación: una mirada desde la teoría crítica. Revista Argumentos, 23(62), 203-224.

Carr, W. and Kemmis, S. (1988). Teoría crítica de la enseñanza. Barcelona: Martínez Roca.

Cook, T., \& Reichardt, C. (2005). Métodos cualitativos y cuantitativos en la investigación evaluativa (5ta ed.). Madrid: Editorial Morata.

Dam, L. (1995). Learner autonomy: From theory to classroom practice. Dublin: Authentik. 
Erdocia, I. (2014). Autonomía y aprendizaje de lenguas. MarcoELE, Revista de didáctica español como lengua extranjera, 0(19), 1-20.

Fandiño, Y. (2010). Research as a means of empowering teachers in the 21st century. Educación y Educadores, 13(1), 109-124. Retrieved from http:// educacionyeducadores.unisabana.edu.co/index.php/eye/article/view/1624/2134

Fandiño, J. \& Bermúdez, J. (2016). Bilingüismo, educación, política y formación docente: una propuesta para empoderar al profesor de lengua extranjera. Bogotá: Panamericana Formas e Impresos S.A.

Fandiño, J., Bermúdez, J, \& Varela, L. (2016). Formación docente en lengua materna y extranjera: un llamado al desarrollo profesional desde el empoderamiento. Revista Virtual Universidad Católica del Norte, 47, 38-63.

Fox, E., \& Riconscente, M. (2008). Metacognition and self-regulation in James, Piaget, and Vygotsky. Educational Psychology Review, 20(4), 373-384. doi:10.1007/s10648008-9079-2.

Gray, D. (2004). Doing research in the real world. London: Sage publications.

Hernández, G., Quiroz, J., \& Olarte, F. (2016). ICT-based strategies for teaching and learning in lesson and unit plans designed by Colombian teachers in a program of educational innovation. Paper presented in the $9^{\text {th }}$ Future of Education International conference, June 27 and 28, Florence, Italy.

Holec, B. (1981). Autonomy and foreign language learning. Oxford: Pergamon Press.

Kimwarey, M. C., Chirure, H., \& Omondi, M. (2014). Teacher Empowerment in Education Practice: Strategies, Constraints, and Suggestions. Journal of research and method in Education, 4(2), 51-56.

Kler, S. (2014). ICT Integration in Teaching and Learning: Empowerment of Education with Technology. Issues and Ideas in Education, 2(2), 255-271.

Koehler, M.J., Mishra, P., \& Cain, W. (2013). What is technological pedagogical content (TPACK)? Journal of Education, 193(3), 13-19.

Littlewood, W. (1999). Defining and developing autonomy in the East Asian context. Applied linguistics, 20(1), 71-94.

Loyens, S. M. M., Magda, J., \& Rikers, M. J. P. (2008). Self-directed learning in problembased learning and its relationships with self-regulated learning. Educational Psychology Review, 20(4), 411-427. doi:10.1007/s10648-008-9082-7. 
Mâță, L. (2012). Key Factors of Curriculum Innovation in Language Teacher Education. International Journal of Educational and Pedagogical Sciences, 6(6), 1222-1230.

Mykhailyshyn, H., Kondur, O., \& Serman, L (2018). Innovation of education and educational innovations in conditions of modern higher education institutions. Journal of Vasyl Stefanyk Precarpathian National University, 5(1), 9-16.

Molba, P.D. (2018). Understanding of the principles of autonomy (part 1). SADJ, 73(6), 418-420.

Mostafa, J., Ahmad, S., Sosahabi, P., \& Berahman, M. (2017). The role of ICT in the learning-teaching process. World scientific news, 0(72), 680-691.

O’Sullivan, D., \& Dooley, L. (2009). Applying innovation. USA: SAGE Publications, Inc.

OECD/CERI. (2010). Inspired by Technology, Driven by Pedagogy. A systemic approach to technology-based school innovations. USA: OECD/CERI.

Puentedura, R. R. (2012). The SAMR model: Background and exemplars. Available at http://www.hippasus.com/rrpweblog/archives/2012/08/23/SAMR BackgroundExemplars.pdf.

Redding, S., Twyman, J. S., \& Murphy, M. (2013). What is an innovation in learning? In M. Murphy, S. Redding, \& J. Twyman (Eds.), Handbook on innovations in learning (pp. 3-14). Philadelphia, PA: Center on Innovations in Learning, Temple University; Charlotte, NC: Information Age Publishing.

Rodríguez, G., Gil, J., y García, E. (1999). Metodología de la investigación cualitativa. España: Ediciones Aljibe.

Serdyukov, P. (2017). Innovation in education: what works, what doesn't, and what to do about it? Journal of Research in Innovative Teaching \& Learning, 10(1), pp.4-33, https://doi.org/10.1108/JRIT-10-2016-0007

Schön, D. A. (1983). The reflective practitioner: How professionals think in action. New York: Basic Books

Singh, H. ve Reed, C. (2001). A white paper: Achieving success with blended learning. Lexington, MA: Centra Software. Available at https://maken.wikiwijs.nl/userfiles/ f7d0e4f0bd466199841ede3eea221261.pdf

Shan, F. (2013). ICT in Education: A Critical Literature Review and Its Implications. International Journal of Education and Development using Information and Communication Technology (IJEDICT), 9(1), 112-125. 
Stenberg, A. (2017). What does Innovation mean - a term without a clear definition. Halmstad University, School of Business, Engineering and Science. Available at http://hh.diva-portal.org/smash/get/diva2:1064843/FULLTEXT01.pdf

Tébar, L. (2003). El perfil del profesor mediador. Madrid: Santillana.

Manen, M.V. (1998). El tacto en la enseñanza. Barcelona: Paidós.

UNESCO. (1990). Innovations and initiatives in teacher education in Asia and the Pacific region. Bankok: Unesco.

UNESCO. (1996). Planning for innovation in education. Paris: International institute for educational planning.

Verd, J. M. y Lozares, C. (2016). Introducción a la investigación cualitativa. Fases, métodos y técnicas. Madrid: Síntesis.

Walker, A., \& White, Goodith. (2013). Technology enhanced language learning. Connecting theory and practice. Oxford: Oxford University Press.

Winters, F., Greene, J., \& Costich, C. (2008). Self-regulation of learning within computer-based learning environments: A critical analysis. Educational Psychology Review, 20(4), 429-444, 2008.

This article was presented in FlipTech Latam 2019 International Conference, in October 2019 


\section{Authors}

${ }^{\star}$ Luis Jesús Rincón-Ussa is an associate professor in the education school at La Salle University, Bogotá, Colombia. He holds an M.Ed. in applied linguistics to teaching English and a B.A. in Modern Languages. His research interests are curriculum management and design, innovation in language teachers education and professional development. Fields of expertise: English teaching and learning methodology, pedagogical practicum supervisor, undergraduate research director, and ICT-mediated language learning.

ORCID: https://orcid.org/0000-0002-5183-6719

Yamith José Fandiño-Parra holds a B.A. in English Philology from the National University of Colombia and an M.A. in Teaching from De La Salle University. He is also a specialist in virtual learning environments from Virtual Educa Argentina. Currently, he is pursuing his $\mathrm{PhD}$ in Education and Society at La Salle University. His research interests range from foreign language learning to teacher education and language policies.

ORCID: https://orcid.org/0000-0002-5567-5465

Andrea Margarita Cortés Ibañez holds a Bachelor of Spanish, English and French from Universidad de La Salle, Bogotá and a Master Degree in Education from the same University. She was a Spanish Language Assistant from 2012-2013 in Kingston, Jamaica. She has been a language teacher at different universities. Currently, she is a full-time teacher and researcher at Universidad de La Salle leading the International Visibility Committee of the Faculty of Education. Her areas of research and interest are didactics of language teaching mediated by ICT and pedagogical practicum in teacher training.

ORCID: https://orcid.org/0000-0002-1063-6235

How to reference this article: Rincón-Ussa, L. J., Fandiño-Parra, Y. J., \& Cortés-Ibañez, A. M. (2020). Educational Innovation through ICT-Mediated Teaching Strategies in the Initial Teacher Education of English Language Teachers. GIST - Education and Learning Research Journal, 21, 91-117. https://doi.org/10.26817/16925777.831 